\title{
Determination of Hematological Status as Health Indicator of European Sea Bass (Dicentrarchus labrax L.) Fed Different Dietary Fatty Acids
}

\author{
Aysel Şahan*, Hatice Asuman Yılmaz, Orhan Tufan Eroldoğan \\ Department of Aquaculture, Fisheries Faculty, Çukurova University, 01330 Sarıçam/Balcalı/Adana, Turkey \\ A R T I C LE IN F O \\ Research Article \\ Received 29 November 2016 \\ Accepted 31 January 2017 \\ Keywords: \\ Sea bass \\ Blood parameters \\ Canola oil \\ Cotton seed oil \\ Fish oil \begin{abstract}
A B S T R A C T
In this study, the European Sea Bass (Dicentrarchus labrax) were fed rich canola oil which is containing monounsaturated fatty acid (MUFA) and rich cottonseed oil which is containing n-6 polyunsaturated fatty acid (PUFA) and the effects of these feeds on some hematological parameters were investigated. Experimental fish were fed two times daily with $100 \%$ fish oil (FO-control), $100 \%$ cottonseed oil (CSO), $100 \%$ canola oil (CO) and $50 \% \mathrm{CSO}-50 \% \mathrm{CO}$ (CSO50-CO50) for 162 days. End of the experiment, total erythrocyte (RBC) amount was highest in the CSO group $269.0 \times\left(10^{4} \mathrm{~mm}^{3-1}\right)$ compared to all other groups. Leukocyte (WBC) $96.280 \times\left(10^{3} \mathrm{~mm}^{3-1}\right)$, monocyte, lymphocyte and neutrophil amounts showed significant increases in only CSO group. Therefore, in terms of fish health and welfare, the exclusive use of cottonseed oil without mixing with the other vegetable oils in sea bass diet formulation can be a viable alternative to fish oil
\end{abstract} \\ since it has the most suitable fatty acids.
}

\footnotetext{
*Corresponding Author:

E-mail: ayaz@cu.edu.tr
}

DOI: https://doi.org/10.24925/turjaf.v5i4.445-450.1106

\section{Introduction}

In the fish feed industry, one of the major issues has been the use of vegetable based oils as alternatives to fish oil due to increased costs of fish oil, which has been due to the reduction of fish stocks and rising demand.

Diets containing lipids are known as an important essential fatty acids and energy source unsynthesized by the fish. Fatty acids are quite important for fish growth, development, cell membrane functions, synthesis of vitamins and hormones, and many other basic functions (Fracalossi and Lovell, 1994; Sheldon and Blazer, 1991). The essential fatty acid balance in the diet is also found to be important for immune system development of fish and other aquatic organisms and for resistance against disease and various stress factors (Montero et al., 2003).

Bio-transformation of linoleic (18:2n-6) and linolenic (18:3n-3) fatty acids in vegetable oils to essential fatty acids is very limited in marine fish species. Therefore, for growth, fertility and healthy development of fishes, polyunsaturated fatty acids (n-6 PUFA) and monounsaturated fatty acids (n-3 MUFA) should be included in the feeds at certain ratios (Mourente and Bell, 2006; Turchini and Francis, 2009).

Fatty acids may not only change the fish metabolism but also may affect fish health and stress resistance of fish. In general, higher levels of substitution by MUFA rich seem to have a detrimental effect on the immune system in salmonids, whereas n-6 PUFA rich vegetable oil appear in marine fish species (Yue and Zhou, 2008; Barros et al., 2002).

Fish health is a complex concept and bases on factors affecting stress. As expected, a variety of factors can affect stress, immunity and pathogen resistance in fish, including the dietary contents of nutrients, fish species, malnutrition, the type and levels of vegetable oil used in the diet (Montero and Izquerdo, 2010).

The inclusion of vegetable oil sources can produce inadequate ratios of n-3 and n-6 fatty acids which could affect fish health by altering the synthesis of eicosanoids (Fracalossi and Lovell, 1994). As stated in a previous study, the use of n-6 and n-3 (PUFA) and MUFA fatty acids as an alternative and source of energy led to significant effects in the immune system and supported macrophage activity of fish (Barros et al., 2002; Montero et al., 2005; Mourente et al., 2007; Montero and Izquerdo, 2010).

Mourente et al. (2007) stated that the use of vegetable derived lipids as an alternative to fish oil yielded optimal growth and feed cycle and can also optimize immune system functions of fishes if it is included in the right amounts.

In this study, the effects of the proportion of different fatty acid classes as an alternative to the omega- 3 rich fish oil on hematological parameters as health indicators were investigated. 


\section{Materials and Methods}

\section{Experimental Diets}

Four diet groups of equivalent crude protein $(\sim 48 \%)$, gross energy $\left(\sim 19.8 \mathrm{MJ} \mathrm{kg}^{-1}\right)$ and lipid $(\sim 22 \%)$ concentrations on a dry weight basis were formulated. CSO (Cotton seed oil) and CO (Canola oil) comprised respectively. Also, the oils blend of these vegetable oils for another experimental diet $\mathrm{CO} \% 50$ - CSO $\% 50$ while the control diet contained $100 \%$ FO. The formulation and proximate composition of the four experimental diets were reported in Table.1. The diets were cold-pelleted with a laboratory pellet mill. Thereafter, the pellets (3 $\mathrm{mm}$ ) were air dried at room temperature over $24 \mathrm{~h}$ period and stored frozen at $-20^{\circ} \mathrm{C}$ throughout the duration of the feeding trial.

In the study, free gossypol which is proved to have toxic effect on fish, removed 0.4-5\% from cottonseed by volatilization as a result of the heat treatment application (Zheng et al., 2012).

\section{Fish Maintenance and Experimental Design}

Sea bass juveniles were obtained from Akuvatur Ltd. (Tuzla, Turkey) for four weeks while they were acclimated to the culture conditions. Following this acclimation period, 20 fish (average initial weight $38.4 \mathrm{~g}$ ) were distributed randomly into 500-L fiberglass tanks that were each supplied with 700-800 $\mathrm{L} \mathrm{min}^{-1}$ of aerated, $27.6 \pm 0.6^{\circ} \mathrm{C}$ sea water $(40 \mathrm{~g} / \mathrm{L})$, dissolved oxygen $(7.2 \pm 0.4 \mathrm{mg} / \mathrm{L})$ and $\mathrm{pH}(7.8 \pm 0.2 \mathrm{mg} / \mathrm{L})$ were measured every 5 days. $12 \mathrm{~h}$ light $-12 \mathrm{~h}$ dark photo-period regime was in effect during the study. The feeding trial lasted 162 days, during which fish were fed two times a day (at 0900 and $1800 \mathrm{~h}$ ) by hand according to visual satiation.

\section{Hematological Analysis}

Fish were starved for $48 \mathrm{~h}$ before sampling, at the end of the feeding trial, weight and length measurements were recorded after all fish in each group were anaesthetized (2-phenoxyethanol at $0.5 \mathrm{~mL} \mathrm{~L}^{-1}$ ) (Sigma-Aldrich AS, MO, USA).

Blood samples collected from the caudal vein of the anaesthetized five fish per dietary group for immediate hematological analysis. Health assessments were performed by measuring several hematological variables including: RBC, WBC, $\mathrm{Hb}$ and Hct amounts, WBC types and RBC indexes. Blood smears were also prepared, dried in air and stained with May Grünwald - Giemsa stains to identify the WBC types as lymphocyte, monocyte, neutrophil, eosinophil.

For RBC and WBC analysis, blood samples were counted in thoma slide with Natt-Herrick solution. Examinations were conducted with Olympus BX 51 light microscope at 4000x magnification. Results were given as $\mathrm{x} 10^{4} \mathrm{~mm}^{3-1}$ for RBC and $\times 10^{3} \mathrm{~mm}^{3-1}$ for WBC. The $\mathrm{Hb}$ $\left(\mathrm{g} \mathrm{dl}^{-1}\right)$ and Hct $(\%)$ levels were determined with the cyanmethaemoglobin and microhaematocrit techniques, respectively (Schreck and Moyle, 1994; Stollen et al., 1994).

RBC indices were calculated by using the following equations (Schreck and Moyle, 1994):
$\mathrm{MCV}=\mathrm{Hct} / \mathrm{RBC} \times 10$
$\mathrm{MCH}=\mathrm{Hb} / \mathrm{RBC} \times 10$
$\mathrm{MCHC}=\mathrm{Hb} / \operatorname{Hct} \times 100$
MVC :Mean Corpuscular Volume $\left(\mu^{3}\right)$
$\mathrm{MCH}$ :Mean Corpuscular Haemoglobin) (pg)
MCHC :Mean Corpuscular Haemoglobin Concentration

Table 1 Formulation and proximate composition $(3 \mathrm{~mm})$ of experimental diets $\left(\mathrm{g} \mathrm{kg}^{-1}\right)$. FO (Fish Oil), CO (Canola Oil), CSO (Cotton Seed Oil).

\begin{tabular}{|c|c|c|c|c|}
\hline \multirow{2}{*}{ Dietary Ingredients } & \multicolumn{4}{|c|}{ Dietary Treatments } \\
\hline & FO & $\mathrm{CO}$ & $\mathrm{CSO}$ & $\mathrm{CO} 50-\mathrm{CSO} 50$ \\
\hline \multicolumn{5}{|l|}{ Diet formulation $\left(\mathrm{g} \mathrm{kg}^{-1}\right)$} \\
\hline Fish meal $^{\mathrm{a}}$ & 510 & 510 & 510 & 510 \\
\hline Corn gluten ${ }^{\mathrm{b}}$ & 225 & 225 & 225 & 225 \\
\hline Dextrin ${ }^{b}$ & 70 & 70 & 70 & 70 \\
\hline Fish oil $^{\mathrm{a}}$ & 100 & - & - & - \\
\hline Cotton seed oil ${ }^{c}$ & - & - & 100 & 50 \\
\hline Canola (Rapeseed) oil ${ }^{\mathrm{c}}$ & - & 100 & - & 50 \\
\hline Carboxy Methyl Cellulose $^{\mathrm{d}}$ & 37 & 37 & 37 & 37 \\
\hline $\mathrm{Cr}_{2} \mathrm{O}_{3}{ }^{\mathrm{e}}$ & 10 & 10 & 10 & 10 \\
\hline Di Calcium Phosphate ${ }^{\mathrm{d}}$ & 23 & 23 & 23 & 23 \\
\hline Mineral mix ${ }^{\mathrm{f}}$ & 15 & 15 & 15 & 15 \\
\hline Vitamin mix ${ }^{\mathrm{f}}$ & 10 & 10 & 10 & 10 \\
\hline \multicolumn{5}{|l|}{ Proximate composition $\left(\mathrm{mg} \mathrm{g}^{-1}\right)$} \\
\hline Moisture & 144.0 & 142.2 & 136.1 & 132.0 \\
\hline Protein & 457.9 & 468.6 & 458.5 & 462.4 \\
\hline Lipid & 204.0 & 195.4 & 200.0 & 192.5 \\
\hline Nitrogen-free extract & 133.7 & 135.4 & 146.9 & 149.2 \\
\hline Ash & 127.2 & 123.2 & 123.0 & 125.1 \\
\hline Gross energy $\left.\mathrm{J} \mathrm{g}^{-1}\right)^{\mathrm{g}}$ & 20.0 & 19.9 & 19.8 & 19.5 \\
\hline
\end{tabular}

${ }^{\mathrm{a}}$ Supplied by Sibal Black Sea Feed, İzmir, Turkey (Anchocy meal-crude protein 70\%), ${ }^{\mathrm{b}}$ Supplied by Sunar Mısır, Adana, Turkey, ${ }^{\mathrm{c}} \mathrm{C} u k u$ urova Corporative Enterprise (Çukobirlik), Adana, Turkey, ${ }^{\mathrm{d}}$ Interlab Laboratory Supplies, İstanbul, Turkey, ${ }^{\mathrm{e}}$ Sigma-Aldrich, Inc., St Louis, MO, USA, ${ }^{\mathrm{f}}$ Vitamin and mineral added minimum to NRC recommendations, ${ }^{\mathrm{g}} \mathrm{Calculated}$ based on the standard physiological fuel values: $19 \mathrm{~kJ} \mathrm{~g}^{-1}$ for protein, 36 $\mathrm{kJ} \mathrm{g}^{-1}$ for lipid and $15 \mathrm{~kJ} \mathrm{~g}^{-1}$ for carbohydrate. 


\section{Statistical Analysis}

Experiments were conducted in triplicate and data obtained from the three replicates were pooled and analysed with One-way-Anova using SPSS statistics 17.0 software (Erol, 2010). Duncan multiple comparison test of the one-way ANOVA was used to compare the mean differences. The differences were considered to be significant at $\mathrm{P} \leq 0.05$.

\section{Results and Discussion}

\section{Results}

The fish were fed the experimental diets for 162 days and formulation, proximate composition of experimental diets were given in Table 1. During the course of the study, no health problems, behavioral disorders or mortality was observed in any group. The hematological parameters monitored of D.labrax fed diets supplemented with FO, CSO, CO and CO50 - CSO50 at the end of 162 days period are presented in Table 2 and Table 3 .

Significant differences in some hematological parameters were observed in fish fed the FO diet, the $\mathrm{CO}$ diet and the CSO diet $(\mathrm{P}<0.05)$. The results indicated that $\mathrm{MCH}$ and $\mathrm{MCHC}$ values were significantly lower in all dietary groups than control group (FO). Also, $\mathrm{MCV}$ value was significantly lower in fish fed the CO diet and CSO diet (Figure 1). In addition, $\mathrm{RBC}$ indexes decreased in a manner inversely proportional to the RBC values.

No detectable variations were found in the Hct and $\mathrm{Hb}$ contents of blood samples in all of the dietary groups (Table 2). The findings of present study have also shown that RBC and WBC amounts were affected in fish fed either the $\mathrm{CO}$ diet or the $\mathrm{CSO}$ diet. $\mathrm{RBC}$ amounts were significantly increased in fish fed the diets with $\mathrm{CO}$ and CSO. The amounts of WBC were found two or three times higher in $\mathrm{CO}$ and $\mathrm{CSO}$ diets than fish fed with FO diet. Blood smears from the experimental groups did not reveal any swelling, shrinkage or other deformations in $\mathrm{RBC}$.

Lymphocyte, monocyte and neutrophil percentages which are major cells of non-specific cellular defense system of fish, were significantly increased in fish fed with CSO diet $(\mathrm{P}<0.05)$. (Table 3 and Figure 2).

Table 2 RBC (Erythrocyte), RBC indices (MCV, MCH, MCHC), Hct (Hematocrit) and Hb (Hemoglobin) amounts of D. Labrax

\begin{tabular}{l|cccc}
\hline \multicolumn{1}{c|}{ Dietary Treatments } & FO & CO & CSO & CO50 - CSO50 \\
\hline RBC $\left(\times 10^{3} \mathrm{~mm}^{3-1}\right)$ & $214.0 \pm 19.7^{\mathrm{a}}$ & $260.0 \pm 15.5^{\mathrm{b}}$ & $269.0 \pm 14.9^{\mathrm{b}}$ & $212.0 \pm 14.4^{\mathrm{a}}$ \\
$\mathrm{Hct}(\%)$ & $34.48 \pm 0.6$ & $37.95 \pm 0.7$ & $34.57 \pm 0.6$ & $36.35 \pm 0.8$ \\
$\mathrm{Hb}\left(\mathrm{g} \mathrm{dl}^{-1}\right)$ & $8.71 \pm 1.5$ & $7.26 \pm 0.7$ & $7.26 \pm 0.4$ & $7.43 \pm 0.2$ \\
$\mathrm{MCV}\left(\mu \mathrm{m}^{3}\right)$ & $1.60 \pm 0.4^{\mathrm{b}}$ & $1.45 \pm 0.2^{\mathrm{a}}$ & $1.28 \pm 0.1^{\mathrm{a}}$ & $1.71 \pm 0.3^{\mathrm{b}}$ \\
$\mathrm{MCH}\left(\mathrm{pg} \mathrm{cell}^{-1}\right)$ & $4.05 \pm 0.9^{\mathrm{c}}$ & $2.82 \pm 0.5^{\mathrm{a}}$ & $2.69 \pm 0.3^{\mathrm{a}}$ & $3.50 \pm 0.7^{\mathrm{b}}$ \\
\hline $\mathrm{MCHC}\left(\mathrm{g} \mathrm{dl}^{-1}\right)$ & $25.26 \pm 3.6^{\mathrm{b}}$ & $19.42 \pm 2.2^{\mathrm{a}}$ & $21.00 \pm 3.0^{\mathrm{a}}$ & $20.44 \pm 2.9^{\mathrm{a}}$ \\
\hline
\end{tabular}

Values in the same line with different superscript are significantly different $(\mathrm{P}<0.05)$.

Table 3 WBC (\%) (Leukocyte), lymphocyte, monocyte and neuthrophil cell amounts of Dicentrarchus labrax

\begin{tabular}{l|cccc}
\hline Dietary Treatments & FO & CO & CSO & CO50 - CSO50 \\
\hline WBC $\left(\times 10^{4} \mathrm{~mm}^{3-1}\right)$ & $6887.50 \pm 9.8^{\mathrm{a}}$ & $11465 \pm 10.5^{\mathrm{b}}$ & $20187 \pm 11.0^{\mathrm{b}}$ & $9831.25 \pm 10.2^{\mathrm{a}}$ \\
Lymphocyte & $93.00 \pm 1.7^{\mathrm{b}}$ & $95.25 \pm 1.1^{\mathrm{b}}$ & $96.28 \pm 3.8^{\mathrm{b}}$ & $86.85 \pm 1.5^{\mathrm{a}}$ \\
Monocyte & $6.75 \pm 1.5^{\mathrm{a}}$ & $5.42 \pm 1.1^{\mathrm{a}}$ & $12.33 \pm 2.3^{\mathrm{b}}$ & $10.28 \pm 1.0^{\mathrm{b}}$ \\
\hline Neuthrophil & $2.00 \pm 0.1^{\mathrm{a}}$ & $\mathrm{NA}^{*}$ & $8.50 \pm 2.0^{\mathrm{b}}$ & $4.00 \pm 1.0^{\mathrm{a}}$ \\
\hline
\end{tabular}

Values in the same line with different superscript are significantly different $(\mathrm{P}<0.05), \mathrm{NA} *$ : Not Avaible

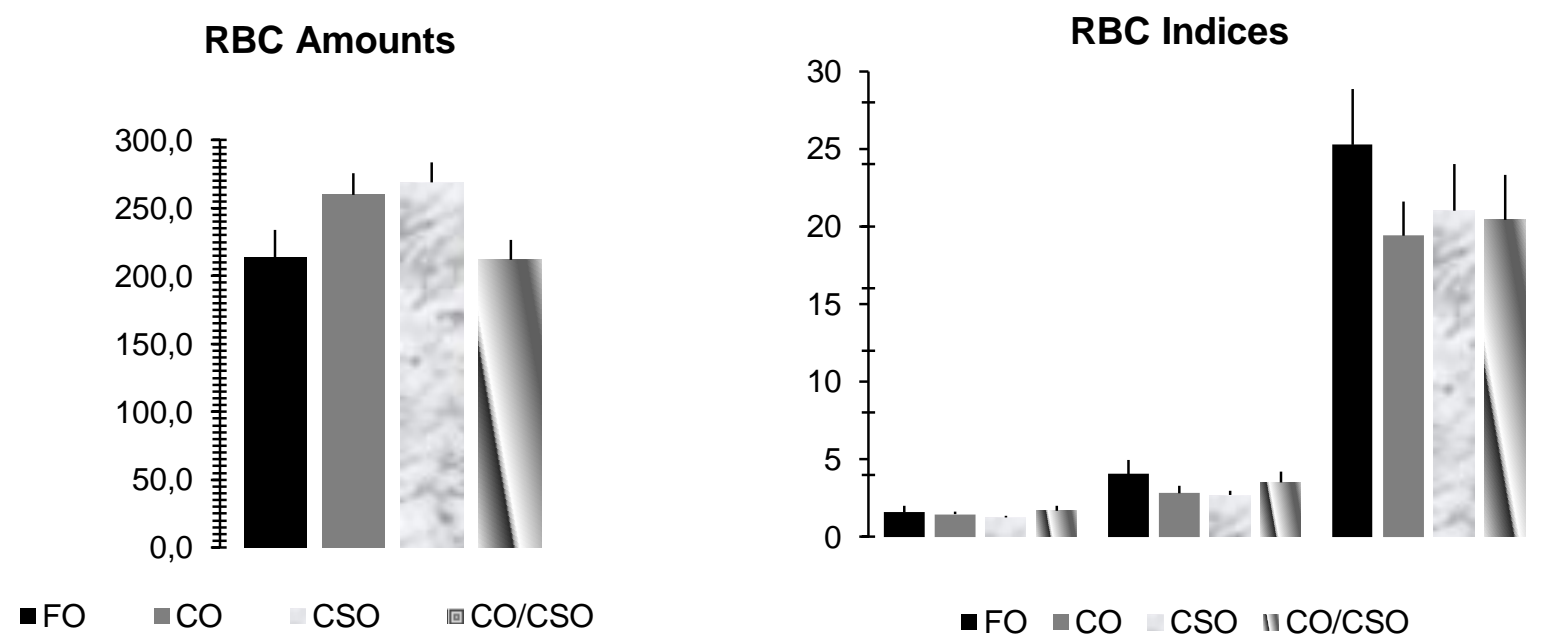

Figure 1 The significant levels of RBC amounts and indices (MCV, MCH, MCHC) 
WBC Amounts

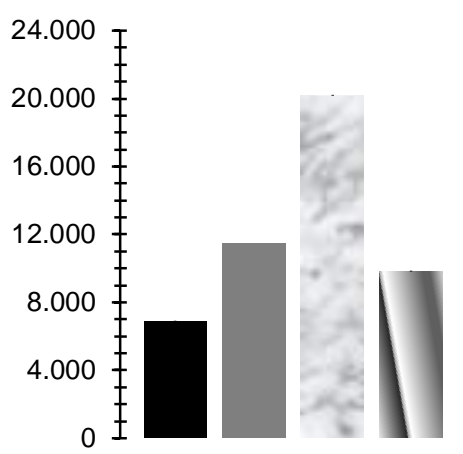

- FO

cso

画 CO/CSO

WBC Types

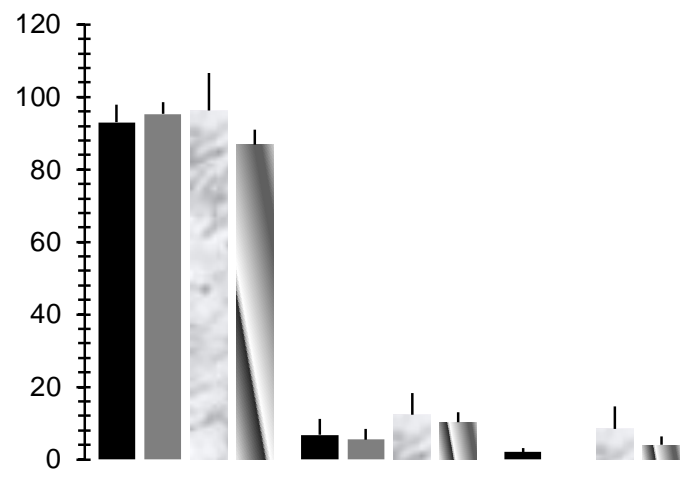

$\because \mathrm{FO} \backsim \mathrm{CO} \triangle \mathrm{CSO} \| \mathrm{CO} / \mathrm{CSO}$

Figure 2 The significant levels of WBC amounts and WBC types (Lymphocyte, Monocyte and Neuthrophil).

\section{Discussion}

The nutritional status of the fish, that individual's resistance against diseases, in which the defense against the worst conditions including malnutrition, and therefore it is very important place in the performance of immune functions.

Therefore, n-6 PUFA or n-3 MUFA which are essential for aquatic organisms, should be mixed to their feed at certain ratios. In previous studies, it has been reported that n-6 PUFA and n-3 MUFA which were used in feed alternatives to fish oil, had no negative effects on fish growth; on the contrary, it was even reported that they supported the growth (Turchini and Francis, 2009; Turchini and Mailler, 2010; Eroldoğan et al., 2013). In particular, MUFA rich canola oil is not prone to oxidation due to its low melting point and natural antioxidant contents, increased digestibility and usability of feed in hot climates. It was found that feeds which were produced with fish meal and fish oil were easily oxidized due to their n-3 PUFA content, which consequently caused peroxidative stress and various health problems (Tocher, 2003). Canola and cotton seed oils have been examined in feeding and growth studies. They are generally preferred worldwide due to their higher production volumes and lower costs compared to fish oil. Additionally, it should be emphasized that these two vegetable oils have been shown to speed growth when used instead of fish oil as a source of energy (Izquerdo et al., 2005; Y1lmaz and Eroldoğan, 2015).

Haematology is a very important as a biological index in determining the health of organism, as pathological indicator, diagnosing the functional status and animal exposed to suspected toxicant. There have been numerous studies into the effects of balanced diet contents on hematological parameters (Robinson and Daniels, 1987; Mourente et al., 2007; Wassef et al., 2007).

In our study, for sea bass fed with vegetable oil including different fatty acids, the values of some hematological parameters as RBC and WBC were significantly higher in the groups in which $\mathrm{CO}$ and $\mathrm{CSO}$ were solely used; RBC indexes decreased in a manner inversely proportional to the RBC values. In the present study, $\mathrm{Hb}$ and Hct amounts were relatively unaffected by experimental diets. Montero et al. (2003) found that seabream Sparus aurata, fed a fish oil diet had higher numbers of circulating erythrocytes compared to fish fed $60 \%$ linseed oil (n-3 PUFA-rich) or soybean oil (n-6 PUFA-rich) diets. This may possibly be related to a higher oxygen requirement due to higher peroximal $\beta$ oxidation activity induced by the vegetable oil diets. RBC indexes are important health indicators used for pathological and physiological diagnosis of diseases. Various studies conducted with healthy fish of different species have revealed that changes in RBC indexes are inversely correlated with the changes in RBC. The changes in RBC indexes of the present study are consistent with the results of previous studies with healthy fish (Schütt et al., 1997; Azizoğlu Şahan, 2000).

Haghighi and Rohani, (2013) erythrocyte cell indexes, such as MCV, MCH and MCHC, are used to diagnose the classification of anemia and the identification of erythrocyte cell activities. Also, MCHC may be attributed to swelling of RBCs due to increased $\mathrm{CO}_{2}$ in blood, anaemia and hyperthermia, hypoxia or stressful in fish. However in the present study, there were no any symptoms of anaemia, hyperthermia and hypoxia condition related with dietary lipid sources.

Wassef et al. (2007) found that a slight deformation in erythrocyte shape was noticed in the blood films of fish fed the vegetable oil (cotton seed oil 60\% and linseed oil $60 \%$ ) diets. In the meantime, no remarkable blood cell morphology alteration was noticed between fish fed control diet. In contrast to previous studies, the addition of a high content of vegetable oil led to no health disorders in any groups according to the blood smear, in which no swelling, shrinkage or deformation were observed in RBC.

A diet with a proper balance of the types and contents of oils and fatty acids has a significant effect on immune system cells of fish, as in all vertebrates (Montero and Izquerdo, 2010). Montero and Izquerdo, (2010) reported 
that when substituting vegetable oils with fish oil in certain proportions, the cellular immunity of fish varied according to the n-3 and n- 6 fatty acid content of the diet. In similar studies conducted on different marine species, peripheral blood leukocytes and functions were affected by the fatty acid profile of the diet. (Sheldon and Blazer, 1991; Montero et al., 2003; Mourente et al., 2007).

Mourente et al. (2007) mentions the study of plant oils are used as an alternative to fish oil, important changes have been determined from the non-specific immune system. Vegetable oil sources were not only important for growth and feed conversion, but also for the functioning of the immune system.

Eroldoğan et al. (2012) found that there were no significant differences on growth performance and health status (normal fin, eyes, gills and mesenteric fat, hindgut and kidney) of sea bass in CSO groups. They suggest that cotton seed oil can used to as a relatively effective substitute for fish oil in European sea bass. Vegetable oils on the growth of sea bass also more effective when used alone, have emphasized that the consequences.

Montero et al. (2003), in contradiction with the results of other studies, reported that the exclusive use of cottonseed oil, linseed oil and sunflower oil were affected the health of fish negatively in terms of stress resistance and immunosuppression. Mourente et al. (2007) emphasized that the replacement of fish oil with vegetable oil has a positive effect on normal immune function and that balanced fatty acid compositions and the alone used of vegetable oils present more physiological benefit .

In the present study, WBC amounts and leucocyte cell types that play a non-specific cellular defense role such as lymphocytes, monocytes and neutrophil cell amounts increased significantly in only CSO group (Figure 2). Thomson et al.(1995) and Bell et al. (1993) indicated that the immune system cells and leukocytes are affected directly by the lipid ratio in the feed. In the previous studies, it was emphasized that, specific ratios of natural feed additives with immunostimulant properties stimulated the immune system, lead to increases in hematological parameters and provided resistance gain in fish (Ajeel and Al-Faragi, 2013; Haghighi and Rohani, 2013; Jeney, et al., 1997; Şahan, et al., 2015).

In the mixed vegetable oil CO50 - CSO50 group, no significant differences were observed in terms of all hematological parameters. In this study, the increase of the basic cells of the cellular immune system in the single fatty acid group (CO or CSO) was found to be consistent with previously conducted studies.

Yue and Zhou, (2008) found that red blood cell counts increased as the replacement of SBM with CSM increased from 0 to $30 \%$ and significantly decreased when the replacement level was above $45 \%$. Hemoglobin significantly decreased with the increase in replacement level. It has been stated that a high dosage of n-3 fatty acids in Atlantic salmon feeds caused an immunosuppressive affect (Erdal et al., 1991).

In a previous study, vegetable oil is used to replace $60 \%$ of fish oil, fish health can be affected in terms of immunosuppression or stress resistance. But sixty percent of fish oil can be replaced by a blend of different vegetable oils without affecting sea bass health (Montero et al., 2003; Robinson and Daniels, 1987). This is similar to the finding of Barros et al. (2002) that channel catfish that fed with meal containing more than $55 \%$ cottonseed meal had health disorders and impaired immune systems (Barros et al., 2002).

In various studies, it has been observed that the replacement of fish oils with $25-60 \%$ vegetable oils did not affect physiological parameters, although for higher vegetable oil content, RBC amount decreased, cell deformations and immunosuppressive conditions were observed (Yue and Zhou, 2008; Erdal et al., 1991; Barros et al., 2002; Robinson and Daniels, 1987).

In the present study, although the ratios of vegetable oils which were used as alternatives to fish oil were increased up to $100 \%$, no health threatening conditions were detected in the hematological parameters; contrary to the previous studies, it was detected that functional blood immune parameters increased.

Conclusively, it was reported that the applied CSO $100 \%$ content, which was higher than has been used in previous studies, supported the hematological parameters that are the most important representatives of both general health and the immune system. This feeding approach may be preferred in order to increase the immune resistance in fish.

Furthermore, in replacing fish oil, the alone use of vegetable oils rather than as a mixture may be more appropriate in terms of fish health effects. This study contributes to knowledge regarding the use of vegetable oils with different fatty acid contents as a substitute for fish oil and thus may serve as a guide for studies concerning disease, welfare and health of fishes.

For practical conclusions, studies need to be conducted on the effect of feeding different vegetable oils on resistance to pathogens, analyzing fish responses in detail.

\section{Acknowledgements}

This study is granted by TUBITAK (Scientific and Technological Research Council of Turkey) research project number 1060195 .

\section{References}

Ajeel SG and Al-Faragi JK. 2013. Effect of ginger, Zingiber officinale and garlic, Allium sativum to enhance health of common carp, Cyprinus carpio. The Iraqi Journal of Veterinary Medicine, 37: 59-62.

Azizoğlu Şahan A. 2000. Haematologic researches on some Cyprinids in Seyhan river (Adana city region). $\mathrm{PhD}$ Thesis, Cukurova University, Adana, Turkey,

Barros MM, Lim C, Klesius PH. 2002. Effect of soybean meal replacement by cottonseed meal and iron supplementation on growth, immune response and resistant of channel catfish (Ictalurus punctatus) to Edwersiella ictaluri challenge. Aquaculture 207: 263-279. DOI: 10.1016/S00448486(01)00740-2. 
Bell JG, McVicar AH, Sargent JR, Thompson KD. 1993. Dietary sunflower, linseed and fish oils affect phospholipid fatty acid composition, development of cardiac lesions, phospholipase activity and eicosanoid production in Atlantic salmon (Salmo salar), Protaglandins Leukotrienes Essent. Fatty Acids 49: 665673. DOI:10.1016/0952-3278(93)90075-8.

Erdal JI, Evensen Q, Kaurstad OK, Lillehaug A, Solbakken R, Thorud K. 1991. Relationship between diet and immune response in Atlantic salmon (Salmo salar L.) after feeding various levels of ascorbic acid and omega-3 fatty acids. Aquaculture 98: 363-379. DOI:10.1016/0044-8486(91)90319-3.

Erol H. 2010. Statistical dataanalyses with SPSS package program. Nobel Publications, Adana, 167-210 pp.

Eroldoğan TO, Turchini GM, Yılmaz HA, Taşbozan O, Engin K, Ölçülü A, Özşahinoğlu I, Mumoğullarında P. 2012. Potential of Cottonseed Oil as Fish Oil Replacer in European Sea Bass Feed Formulation. Turkish Journal of Fisheries and Aquatic Sciences 12: 787-797. DOI: 10.4194/1303-2712-v12_4_07.

Eroldoğan TO, Yılmaz AH, Turchini GM, Arslan M, Sirkecioğlu NA, Engin K, Özşahinoğlu I, Mumoğullarında P. 2013. Fatty acid metabolism in European sea bass (Dicentrarchus labrax): effects of n-6 PUFA and MUFA in fish oil replaced diets. Fish Physiol Biochem. 39(4): 941-55. DOI: 10.1007/s10695-0129753-7.

Fracalossi DM, Lovell RT. 1994. Dietary lipid sources influence responses of channel catfish (Ictalurus punctatus) to challenge test with the pathogen Edwardsiella ictaluri. Aquaculture 119: 287-298. DOI: 10.1016/0044-8486(94)90183-X.

Haghighi M, Rohani MS. 2013. The effects of powdered ginger (Zingiber officinale) on the haematological and immunological parameters of rainbow trout Oncorhynchus mykiss asoud. Journal of Medicinal Plant and Herbal Therapy Research 8-12.

Izquierdo MS. Montero D, Robaina L, Caballero MJ, Rosenlund G, Gines R. 2005. Alterations in filet fatty acid profile and flesh quality in gilthead seabream (Sparus aurata) fed vegetable oils for a long term period. Recovery of fatty acid profiles by fish oil feding. Aquaculture 250: 431- 444. DOI: 10.1016/j.aquaculture.2004.12.001

Jeney G, Galeotti M, Volpatti D, Jeney Z, Anderson DP. 1997. Prevention of Stress in Rainbow Trout (Oncorhynchus mykiss) Fed Diets Containing Different Doses of Glucan. Aquaculture, 154(1):1-15. doi: 10.1016/S0044- 8486(97)00042-2

Montero D, Kalinowski T, Obach A, Robaina L, Tort L, Caballero MJ, Izquierdo MS. 2003. Vegetables lipid sources for gilthead seabream (Sparus aurata): effects on fish health. Aquaculture 225: 353-370. DOI: /10.1016/S0044-8486 (03)00301-6.

Montero D, Robaina L, Caballero MJ, Gines R, Izquierdo MS. 2005. Growth, feed utilization and flesh quality of European sea bass (Dicentrarchus labrax) fed diets containing vegetable oils. Aquaculture 248: DOI:10.1016/j.aquaculture.2005.03.003.

Montero D, Izquierdo M. 2010.Welfare and Health of Fish Fed Vegetable Oils as Alternative Lipid Sources to Fish Oil. Boca Raton, U.S: CRC Press.

Mourente G, Bell JG 2006. Partial replacement of dietary fish oil with blends of vegetable oils (rapeseed, linseed and palm oils) in diets for European sea bass (Dicentrarchus labrax L.) over a long term growth study: effects on muscle and liver fatty acid composition and effectiveness of a fish oil finishing diet. Comparative Biochemistry and Physiology 145, 389-399. DOI:10.1016/j.cbpb.2006.08.012.
Mourente G, Good JE, Thompson KD, Bell JG. 2007. Effects of partial substitution of dietary fish oil with blends of vegetable oils, on blood leukocyte fatty acid compositions, immune function and histology in European sea bass (Dicentrarchus labrax L.). British Journal of Nutrition 98: 770-779. DOI: 10. 1017/S000711450773461X.

Robinson EH, Daniels WH. 1987. Substitution of soybeanmeal with cottonseed meal in pond feeds for channel catfish reared at low densities. J. World Aquac. Soc. 18: 101-106. DOI: 10.1111/j.1749-7345.1987.tb00424.x.

Schreck CB, Moyle PB. 1994. Methods for Fish Biology. American Fisheries Society, Maryland, USA: Exon Company

Schütt DA, Lehmann J, Goerlich R, Hamers R. 1997. Hematology of Swordtail, Xiphophorus helleri. I: Blood parameters and light microscopy of blood cells. J Appl Ichthyology 83-89. DOI: $10.1111 /$ j.1439-0426.1997.tb00106.x.

Sheldon WH, Blazer VS. 1991. Influence of dietary lipid and temperature on bactericidal activitiy of channel catfish macrophages. J Aqua Anim Health 3: 87-93.DOI: 10.1577/1548-8667(1991)003<0087:IODLAT>2.3.CO;2.

Stollen SJ, Fletcher TC, Anderson DP. 1994. Techniques in fish immunology-2. $1^{\text {st }}$ edition., Virginia: SOS Publications. ISBN 0-9625505-3-1.

Şahan A, Taşbozan O, Aydın F, Özütok S, Erbaş C, Duman S, Uslu L, Özcan F. 2015. Determination of some haematological and non-specific immune parameters in Nile Tilapia Oreochromis niloticus 1., 1758) fed with spirulina (Spirulina platensis) added diets. journal of aquaculture engineering and fisheries research. 1(3): 133-139. doi:10.3153/JAEFR15014.

Thompson KD, Henderson RJ, Tatner MF. 1995. A comparison of the lipid composition of peripheral blood cells and head kidney leukocyte of Atlantic salmon (Salmo salar L.). Comp Biochem Physiol B Biochem Mol Biol 112: 83-92. DOI:10.1016/03050491(95)00051-9.

Tocher DR. 2003. Metabolism and functions of lipids and fatty acids in teleost fish. Reviews in Fisheries Science 11: 107- 184. DOI: $10.1080 / 713610925$.

Turchini GM, Francis DS. 2009. Fatty acid metabolism (desaturation, elongation and beta-oxidation) in rainbow trout fed fish oil- or linseed oilbased diets. British Journal of Nutrition 102: 69-81. DOI: 10.1017/S0007114508137874.

Turchini GM, Mailler RJ. 2010. Rapeseed (Canola) oil and other monounsaturated fatty acid-rich vegetable oils. Turchini, Tocher, Tailer and Francis, Boca Raton, Fl, USA: CRC Press

Wassef EA, Wahby OM, Sakr EM. 2007. Effect of dietary vegetable oils on health and liver histology of gilthead seabream (Sparus aurata) growers. Aquacult Res. 38:852-861. DOI: $10.1111 /$ j.1365-2109.2007.01738.x.

Y1lmaz HA, Eroldoğan OT. 2015. Effects of fish oil substitution with two different vegetable oil classes on fatty acid digestibility in juvenile European Sea Bass, Dicentrarchus labrax. Turkish Journal of Fisheries and Aquatic Sciences, 15, 1-12. DOI: 10.4194/1303-2712-v15_1_01.

Yue YR, Zhou QC. 2008. Effect of replacing soybean meal with cottonseed meal on growth, feed utilization and hematological indexes for juvenile hybrid tilapia, tilapia Oreochromis niloticus (L.) x O.aureus. Aquaculture 284: 185-189. DOI: 10.1016/j.aquaculture.2008.07.030.

Zheng Q, Wen X, Han C, Li H, Xie X. 2012. Effect of replacing soybean meal with cottonseed meal on growth, hematology, antioxidant enzymes activity and expression for juvenile grass carp, Ctenopharyngodon idellus. Fish Physiol Biochem 38: 1059 -1069. DOI: 10.1007/s10695-011-9590-0. 